\title{
Black Harrier Circus maurus of the Fynbos biome, South Africa: a threatened specialist or an adaptable survivor?
}

\author{
ODETTE CURTIS, ROBERT E. SIMMONS and ANDREW R. JENKINS
}

\begin{abstract}
Summary
Black Harrier Circus maurus is a rare southern African endemic that may have lost over $50 \%$ of its core breeding habitat in the last century as a result of extensive land transformation by agriculture, invasive alien vegetation and urbanization in the Fynbos biome. We partially surveyed both the western (Swartland) and southern (Overberg) coastal plains of south-western South Africa, over 3 years (2000-2002) for breeding Black Harriers, and found a distinctly polarized distribution. Nests were concentrated either along the coastal strip or inland in montane habitats, and generally absent from heavily cultivated and transformed inland plains areas. Limited evidence (direct observations, prey remains) suggests that harriers forage in cereal croplands but generally do not breed in these modified environments. We recorded breeding success at nests in coastal (Dune Thicket) and montane (Mountain Fynbos) habitats. Harriers bred successfully along the coast and nests were aggregated in loose colonies around wetlands. Harriers in montane environments bred poorly, took a wide range of prey, and were subject to high levels of nest predation. We propose that Black Harriers have been displaced from lowland Renosterveld and Fynbos habitats (characterized by better foraging and nesting opportunities), primarily by the advent and spread of cereal agriculture. The conservation and future research implications of this hypothesis are discussed.
\end{abstract}

\section{Introduction}

Black Harrier Circus maurus has the most restricted range of any continental harrier species (Simmons 2000), and is essentially endemic as a breeding species to the Fynbos biome of south-western South Africa, with peripheral populations in the southern reaches of the Karoo and Grassland biomes. It is classified as Near Threatened within its South African range (Barnes 2000) and globally Vulnerable (BirdLife International 200o), with an estimated total world population of 1,000-2,000 birds (van der Merwe 1981, Siegfried 1992).

Opinions on the historical and present conservation status of Black Harrier have varied (Van der Merwe 1981). In terms of the current condition of environments within its core breeding distribution, the species has conceivably lost as much as $50 \%$ of its preferred natural habitat to the spread of cereal agriculture and viticulture, alien vegetation and urbanization. This applies particularly to the fertile, lowland areas of the western and south-western coastal plains of South Africa, where over 90\% of the natural vegetation has been transformed by agriculture in the last 100-150 years (Allan 1993, Low and Rebelo 1996, Kemper et al. 2000). However, because there is no reliable information on pre-transformation harrier populations, and the habitat affinities of the species 
are poorly understood, the actual effects of anthropogenic landscape change remain unclear.

This paper examines the evidence for the detrimental effects of land transformation on Black Harrier. Results from distribution surveys of breeding pairs in parts of the south-western Cape are presented, coupled with data on the biology and breeding performance of a sample of small focal populations, across a spectrum of habitat types. Hypothetically, if the harrier has been forced to vacate favoured habitats with the encroachment of agriculture, breeding pairs may have been restricted to sub-optimal habitats, with performance-linked consequences. Alternatively, the species may never have depended on those areas most heavily affected by human activities, or may be sufficiently adaptable to have easily endured or even exploited the effects of habitat change.

\section{Methods}

\section{Surveys and study areas}

Fieldwork was conducted from June to December over 3 years (2000-2002). We surveyed harriers within the Fynbos biome, and specifically within either the west (Swartland) or south (Overberg) coastal plains (Figure 1), in two ways, neither of which was particularly systematic, but in combination yielded good coverage of much of the available habitat. We conducted opportunistic road transects, and drove about 4,000 $\mathrm{km}$ through apparently suitable foraging and/or nesting areas. Whenever Black Harriers were seen we stopped to observe

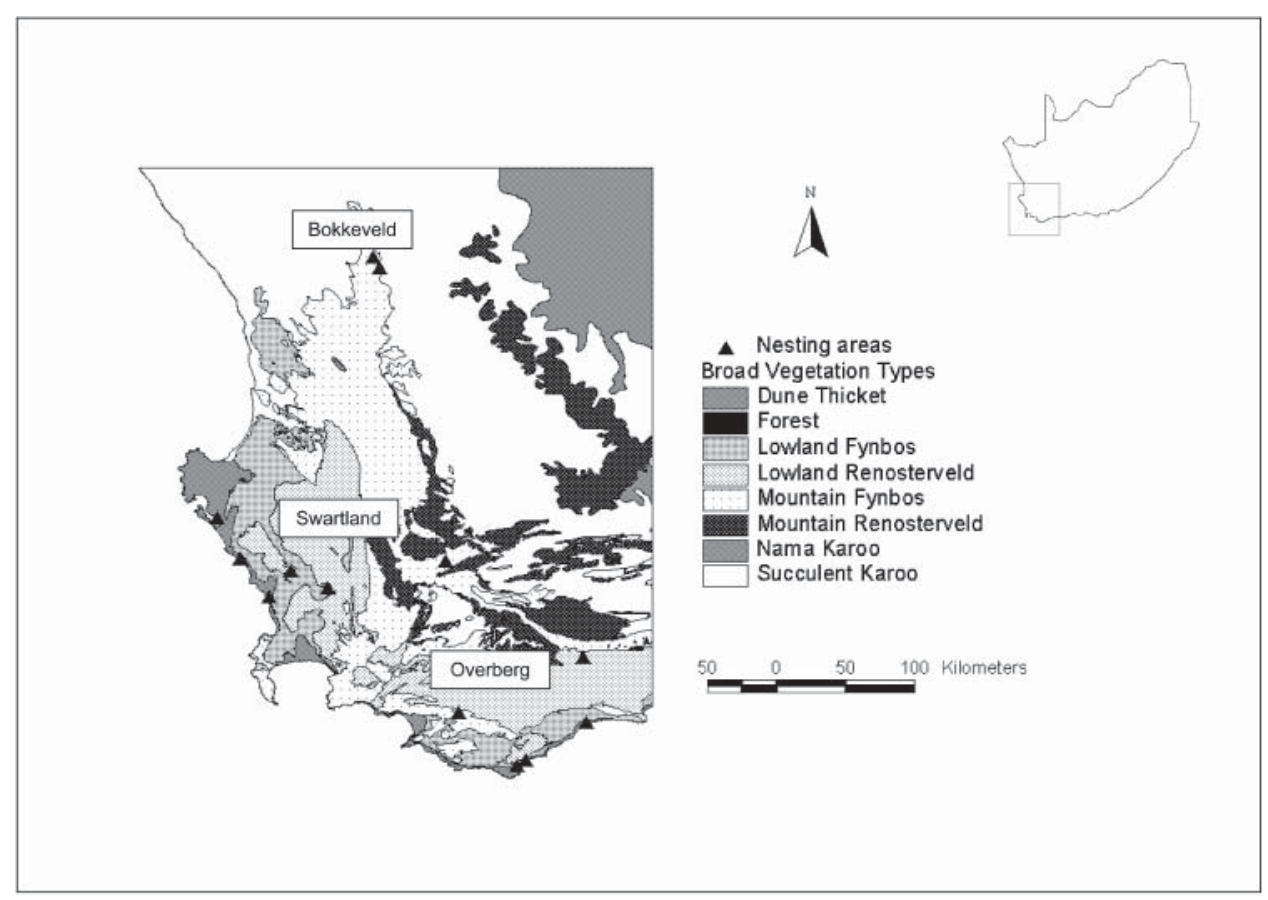

Figure 1. Map of Black Harrier nesting areas and broad vegetation types (adapted from Low and Rebelo 1996) in the Fynbos biome, southwestern Cape, South Africa (2000-2002). 
them in the hope that this might lead to the discovery of new breeding areas. We also canvassed local ornithologists for information on where they had regularly seen harriers.

Areas thought likely to support harrier pairs (on the basis of our own observations, or published, reported or solicited information) were surveyed initially from a prominent vantage-point. Specific sites that were frequented by adult birds were visited and inspected for signs of breeding activity. Once active nests were located, we searched the general vicinity for more, and also enrolled the help of land-owners to locate and monitor nests in some areas. In this way, we established focal "populations" of harriers, located in three biologically and climatically discrete areas that essentially covered the spectrum of major habitats occupied by breeding pairs in the Fynbos biome.

The Bokkeveld area (Figure 1) in Northern Cape Province is fringed by the Bokkeveld escarpment, with a hilly, semi-arid plateau extending to the east. Vegetation includes elements of Mountain Fynbos (moist, montane heathland), Escarpment Mountain Renosterveld (drier, grassy heathland with a predominance of geophytes) and Upland Succulent Karoo (dry, succulent shrubland) (Low and Rebelo 1996). Altitude ranges from 600 to $900 \mathrm{~m}$ a.s.l., and the climate features cold, wet winters and warm, dry summers, with a mean annual rainfall of $300 \mathrm{~mm}$. The region is sparsely populated, with the small town of Niewoudtville $\left(31^{\circ} 23^{\prime} \mathrm{S}, 19^{\circ} \mathrm{O}^{\prime} \mathrm{E}\right)$ the main commercial centre. Cereal agriculture is widespread and has transformed much of the area's natural vegetation.

The West Coast and Swartland area (Figure 1) extends along the south-west coast of the Western Province, from the city and suburbs of Cape Town $\left(33^{\circ} 56^{\prime} \mathrm{S}\right.$, $18^{\circ} 25^{\prime} \mathrm{E}$ ) in the south-west to the rural towns of Velddrif, Piketberg and Paarl in the north-west, north-east and south-east respectively. Vegetation varies from Dune Thicket on the coast, to Sand Plain Fynbos and West Coast Renosterveld in the lowlands, and Mountain Fynbos inland and at higher altitudes (Low and Rebelo 1996). Altitude ranges from sea level to about $900 \mathrm{~m}$ a.s.l., and the climate is temperate, with a mean annual rainfall of $430 \mathrm{~mm}$, falling mostly in winter, and mean minimum and maximum temperatures of about $12^{\circ} \mathrm{C}$ and $24^{\circ} \mathrm{C}$. Cereal agriculture and viticulture are the main forms of land-use. Large stretches of the coastal strip are contained in private and state-owned conservation areas. Inland, over $90 \%$ of the natural environment has been transformed by agriculture, leaving only small, isolated fragments of natural vegetation along drainage lines or in higher-lying areas.

The Overberg area (Figure 1) extends along the south coast of the Western Province, from approximately Caledon $\left(34^{\circ} 15^{\prime} \mathrm{S}, 19^{\circ} 20^{\prime} \mathrm{E}\right)$ in the west to Albertinia in the east, and south to the Agulhas Plain. Vegetation ranges from East Coast Dune Thicket to Limestone Fynbos and South Coast Renosterveld in the lower-lying areas, to Mountain Fynbos further inland and at higher altitudes (Low and Rebelo 1996). About 80\% of the lower-lying areas have been transformed into tracts of cereal agriculture and pastures (Kemper et al. 200o), while some extensive coastal and montane areas remain largely intact. Rainfall patterns vary from west to east, with winter rainfall in the west and a bimodal springautumn regime in the east (Low and Rebelo 1996, Kemper et al. 2000). Mean annual rainfall ranges from 350 to $600 \mathrm{~mm}$ (Kemper et al. 2000). 


\section{Nest monitoring}

Although we did not observe harriers using the same nest structure in consecutive years of the study, where pairs bred in the same general area over the 3 years, we considered this to be a single nesting site.

GPS locations were recorded for all active nests. Nest visits, and resulting disturbance of vegetation around the nest, were kept to a minimum to reduce the chances of observer-induced nest predation. On first locating each active nest we recorded clutch or brood size, together with a number of basic habitat parameters describing the immediate vicinity (general location and surrounding topography, prevailing vegetation type, dampness of the substrate, altitude).

\section{Diet}

Limited information on diet was obtained from field observations of adults carrying or eating prey. Distance generally precluded specific identification, but it was usually possible to categorize prey as either small mammal, bird or reptile. Macro-remains (mostly larger skeletal fragments and feather-pluckings) found on or near nests were collected opportunistically.

\section{Results}

\section{Nesting habitat and density}

Basic habitat parameters were recorded at a total of 48 Black Harrier nest-sites (Appendix, Table 1), while the total number of monitored breeding attempts exceeded this figure (see below). All nests were positioned on the ground in knee- to shoulder-high vegetation, often in damp areas, although about a third of all nests were situated on dry ground. All eight nests in the Bokkeveld area (Figure 1) were located in montane situations and in damp to wet habitats. Nests were quite widely spaced, with the closest known active sites almost $2 \mathrm{~km}$ apart. Twenty-nine nest-sites in the West Coast and Swartland area (Figure 1) were located either on the upper slopes of a low mountain range (the Perdeberg, Appendix), in areas of fairly dense, grassy, well-watered Mountain Fynbos (dominated by Leucospermum, Berzelia, Protea and restioid species), or in flat, coastal habitats, dominated by Dune Thicket vegetation (Appendix). Three focal areas were identified along the coast: Koeberg Nature Reserve, Jakkalsfontein Private Nature Reserve and the West Coast National Park (WCNP) (Appendix). At Koeberg, five of six nest-sites were grouped together (100-290 m apart) in what was previously open dune habitat, replaced by a mix of exotic marram grass Ammophila arenaria (planted to stabilize the dunes) (H. Westman pers. comm.) and thickets of indigenous Strandveld vegetation (predominantly Myrica cordifolia). Six nest-sites at Jakkalsfontein, and 11 at the WCNP, were located in or on the fringes of wetlands or saltmarshes in areas of Dune Thicket, and covered either by tracts of Juncus krausii or by Cliffortia sp. Nest-sites at Jakkalsfontein were associated with small, ephemeral pans, and were quite widely spaced (minimum distance apart $590 \mathrm{~m}$ ), while those at the WCNP were closely (minimum $120 \mathrm{~m}$ ) and linearly arranged along the southern edge of the Langebaan lagoon, between stands of reeds (Phragmites sp.). Only two nests were located inland, in lowland Fynbos vegetation, on dry ground. The first was found in a 
Table 1. Summary of Black Harrier nests in different areas, habitats and vegetation types in the Fynbos biome, southwestern Cape, South Africa (2000-2002).

\begin{tabular}{lllrr}
\hline Study area & Fynbos & Renosterveld & Dune Thicket & Total \\
\hline Coastal & & & & \\
Bokkeveld & 0 & - & 0 & 0 \\
West Coast and Swartland & 0 & - & 23 & 23 \\
Overberg & 2 & - & 4 & 6 \\
Total & 2 & - & & 29 \\
Inland lowland & & & - & \\
Bokkeveld & 0 & 0 & - & 2 \\
West Coast and Swartland & 1 & 1 & - & 1 \\
Overberg & 0 & 1 & - & 3 \\
Total & 1 & 2 & - & \\
Montane & & & - & 4 \\
Bokkeveld & 1 & 7 & - & 4 \\
West Coast and Swartland & 4 & 0 & - & \\
Overberg & 4 & 0 & & \\
Total & 9 & 7 & 0 & 29 \\
All areas & & & 23 & 11 \\
Bokkeveld & 1 & 7 & 4 & 48 \\
West Coast and Swartland & 5 & 1 & & \\
Overberg & 6 & 9 & & \\
Total & 12 & & & \\
\hline
\end{tabular}

patch of Sand Plain Fynbos near Grotto Bay (Appendix), and the second was in an isolated fragment of West Coast Renosterveld at Riverlands Nature Reserve, near Malmesbury (Appendix).

Eleven nest-sites in the Overberg (Figure 1) were spread over a diverse range of habitat types. Four sites were located in Mountain Fynbos, five in coastal Dune Thicket, one in Limestone Fynbos and one in South Coast Renosterveld.

While harriers were surveyed and observed in three geographically discrete study areas, the majority of nests in our sample were found in either montane $(33 \%)$ or coastal situations (61\%) (typified by either Fynbos, Renosterveld vegetation or Dune Thicket respectively) (Table 1 ), with only three nests $(6 \%)$ found in the intervening inland lowland areas. We found no nests in transformed habitat of any kind, and $65 \%$ of nests were located in formally declared conservation areas, with most of the remaining sites in private conservancies. Subsequently, the montane vs coastal dichotomy was deemed the most convenient and biologically meaningful way to divide and compare breeding data.

\section{Breeding success}

In the 3 years of the study we monitored a total of 83 Black Harrier breeding attempts (Appendix). Egg-laying took place from June to November, with the peak laying months being September (38\% of clutches) and July (22\%). Mean clutch size was $3.5 \pm 0.7$ eggs $(n=58$ clutches). Brood size averaged $2.3 \pm 1.1$ ( $n=61$ broods) and fledged broods averaged $1.9 \pm 1.2(n=53$ broods). 
Egg hatchability (the proportion of viable eggs in all fully incubated clutches) was $74 \%$ ( $n=25$ clutches), while hatching success (the proportion of eggs converted to hatched young, incorporating the effects of both clutch failure and nest predation) was $63 \%$ ( $n=48$ clutches). About a quarter $(26 \%)$ of nests followed to completion were subject to nest predation, including incidents of egg predation $(n=11)$ and nestling predation $(n=3)$, and on one occasion a breeding attempt failed when an adult harrier was taken by a predator.

Mean laying date, mean clutch size and mean fledged brood size varied significantly between years (Table 2), with the earliest and most productive breeding occurring in 2002.

At coastal sites, average laying date and clutch size varied significantly over the 3-year study period, while at montane sites, only laying date showed any significant variation between years (Table 2). Except in 2001, sample sizes were mostly too small in the montane area to make meaningful comparisons between areas within years, so breeding success in the two areas was compared in terms of all the data for each area pooled across years, and in terms of the data for 2001 only (Table 3 ).

For all years, harriers breeding at coastal sites were more successful than those at montane sites: coastal pairs started breeding earlier (Table 3), hatched larger broods and fledged more young (Table 3) than montane pairs. Nest predation rates were higher at montane nests than at coastal nests $(53 \%$ vs $18 \%$, Fisher exact test, one-tailed, $P=0.0135)$. The data for 2001 largely confirm these results (Table 3).

\section{Diet}

Overall, small mammals dominated Black Harrier diet in our study, comprising $69 \%$ of all identified prey individuals $(n=97)$. However, diet differed substantially between coastal and montane sites. Harriers on the coast $(n=53$ identified prey individuals) fed chiefly on mammals (86\%) and took relatively few birds $(6 \%)$ and reptiles $(8 \%)$, while those breeding in montane areas $(n=44$ identified prey individuals) took more birds (52\%) (mostly Common Quail Coturnix coturnix), fewer mammals (48\%) and no reptiles. Data were insufficient to allow for comparisons between years.

\section{Discussion}

Breeding distribution: exclusion or selection?

Although we surveyed transformed lowland landscapes on both the western and southern coastal plains of the Fynbos biome, we found very few harriers nesting in these areas. While more thorough and structured surveys, particularly of the remaining fragments of natural habitat, may reveal more harriers breeding in the lowlands, our study has clearly shown a polarized distribution, with the majority of nests concentrated along the coastal strip and inland in the mountains.

This distribution essentially reflects land-use patterns in the region, with intensive agricultural development concentrated in the flat, relatively fertile lowlands, and largely absent along the coast and on the steeper slopes and higher-lying areas. Published information (e.g. Van der Merwe 1981, Steyn 1982), our own 


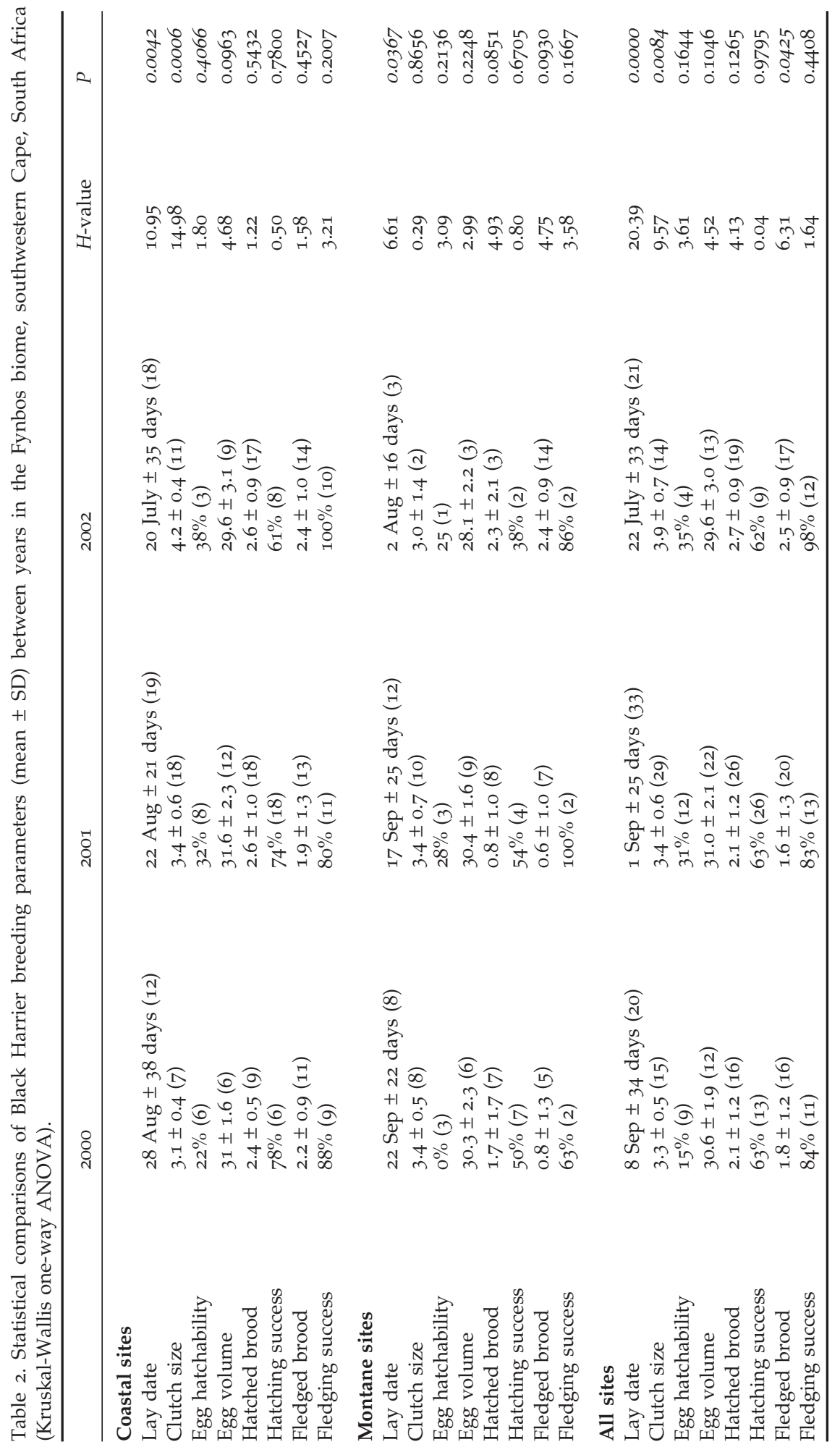




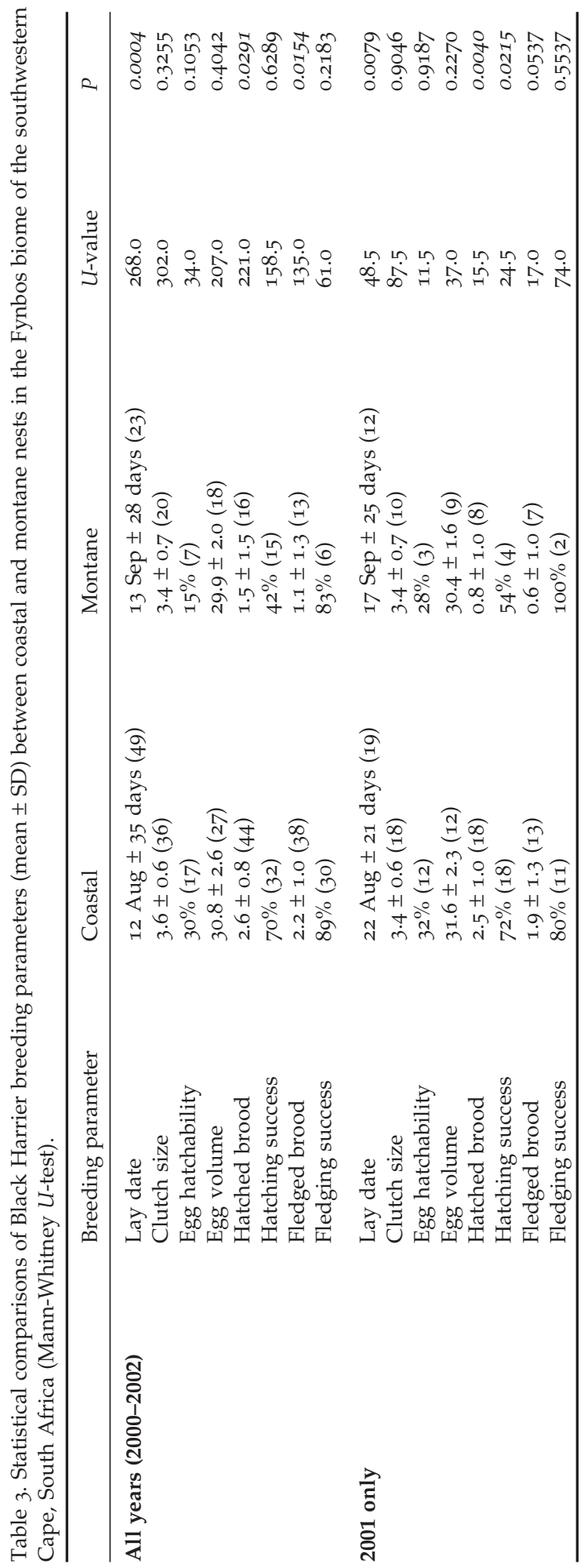


incidental observations and the propensity of some pairs to prey heavily on species that are concentrated in wheat fields (e.g. Common Quail; Hockey et al. 1989) all suggest that Black Harriers regularly forage in these transformed habitats. However, unlike some of the Northern Hemisphere harriers (e.g. Hen Harrier C. cyaneus and Montagu's Harrier C. pygargus; Millon et al. 2002, Arroyo et al. 2002), Black Harrier seems largely incapable of nesting in cultivated areas (there are only two records of Black Harriers breeding in cultivated areas out of a total of 82 documented nest-sites; this study, Chadwick 1997, Allan et al. 2001, B. Visser pers. comm.), and has so far shown no obvious signs of developing such behavioural plasticity.

The absence of breeding Black Harriers from most of the cultivated areas of the Swartland and Overberg supports the contention that the species has been negatively affected by land transformation. However, the significance of this effect depends largely on the extent to which harriers used lowland Renosterveld and Fynbos habitats before they were transformed, which is difficult to determine, given that there are no informative data in the historical literature. Evidence that harriers regularly forage over cereal croplands, away from nesting areas, could suggest that prey availability near nests is insufficient to sustain breeding pairs. This deficiency could be a function of the accessibility (rather than the abundance) of prey in different habitats. Most nests are presently situated either in Dune Thicket or Mountain Fynbos (Appendix). These are both relatively tall, closed and structurally complex vegetation types, which may impair the harriers' ability to locate and catch prey. In contrast, while cereal fields might support lower prey densities than adjacent natural vegetation (van Wyk and van Hensbergen 1995), rodents and birds are probably easier to access in these more open and structurally simple habitats (e.g. Preston 1990, Simmons 2000, Redpath et al. 2002).

Therefore, lowland Renosterveld and Fynbos habitats are typically less complex and more open than coastal or montane vegetation, and may present better harrier foraging returns for breeding harriers. This, coupled with the location of at least some active nests $(n=3)$ in these habitats, confirms their potential to support significant numbers of breeding birds.

A possible alternative explanation for the low numbers of breeding Black Harriers in inland-lowland vegetation could be that this species is temperature sensitive, to the extent that environments without the moderating influence of either the proximity to the cool sea or higher altitudes are unfavourable, and that these cooler zones are actively selected by nesting birds. For example, recent evidence suggests that Hen Harrier and Montagu's Harrier are reproductively stressed in warmer and cooler breeding environments (Garcia and Arroyo 2001, Redpath et al. in press). They may therefore be selecting apparently cooler areas to breed in (i.e. on the coast or at higher altitudes).

We found harriers nesting in loose aggregations at some of our focal sites, perhaps because these areas include vital, localized microhabitat features. For example, on the west coast, nests were generally located in longer, hydrophilic vegetation, and loose colonies formed close to saltpans and other waterbodies. This semi-colonial condition may occur naturally (as it does in other harrier species; Simmons 2000), but could also reflect the exclusion of the population from optimal breeding habitats (e.g. along drainage lines in lowland Fynbos or 
Renosterveld) by land transformation. Perhaps significantly, the latter scenario may bring Black Harrier into competition for resources with African Marsh Harrier C. ranivorus, a threatened wetland specialist (Simmons 1997, Barnes 2000). Interactions between these two species (e.g. Chadwick 1997), and partitioning of the harrier niche where they occur in sympatry, should be studied more closely.

\section{Breeding performance: marginalization or optimization?}

The markedly inferior performance of Black Harriers nesting in montane habitats may be explained in terms of two contributing factors. Firstly, we saw very little active foraging by harriers close to nests in these areas, and much of the avian prey they delivered to nests was probably caught in cereal croplands or lowland Fynbos at least $3-4 \mathrm{~km}$ away and $300-400 \mathrm{~m}$ lower in altitude. Longer foraging ranges probably increased energetic demands on provisioning adults, reducing the frequency of food deliveries, and depressing clutch size and nestling growth rates (Simmons 1986, Jenkins 2000). Secondly, over half the montane nests we monitored were subject to high levels of predation. Hence, of the two broad habitat types predominantly used by Black Harrier pairs in the Fynbos biome (coastal and montane environments), at least one is apparently less than optimal for successful breeding.

This result is subject to verification as the spatial and temporal scope of our research develops. Also, significant inter-annual variation in breeding performance (Table 2) suggests that Black Harriers may be sensitive to short-term fluctuations in local conditions (Simmons 1997, 2000), so patterns in breeding performance observed to date could be altered if, for example, prevailing climatic conditions in our respective study areas are subject to substantial change.

\section{Black Harriers and lowland habitat conservation}

We propose that the modern breeding distribution of Black Harrier is an artefact of land transformation, and that breeding pairs have been excluded from vast areas of prime habitat. This process is continuing as agriculture and urbanization continue to spread.

More comprehensive data on harrier foraging and breeding performance in different habitats, and under different conditions of land-use, are required to fully test this hypothesis. In particular, the distribution and success of harrier pairs in the lowlands in relation to the distribution and quality of natural habitat remnants needs to be clarified. Demonstration of a link between the welfare of harrier pairs and the ecological integrity of habitat fragments could establish Black Harrier as a valuable surrogate species for broader conservation initiatives in the Fynbos biome.

\section{Acknowledgements}

We thank the Cape Bird Club for their generous sponsorship of this project. SA National Parks and the Western Cape Nature Conservation Board kindly 


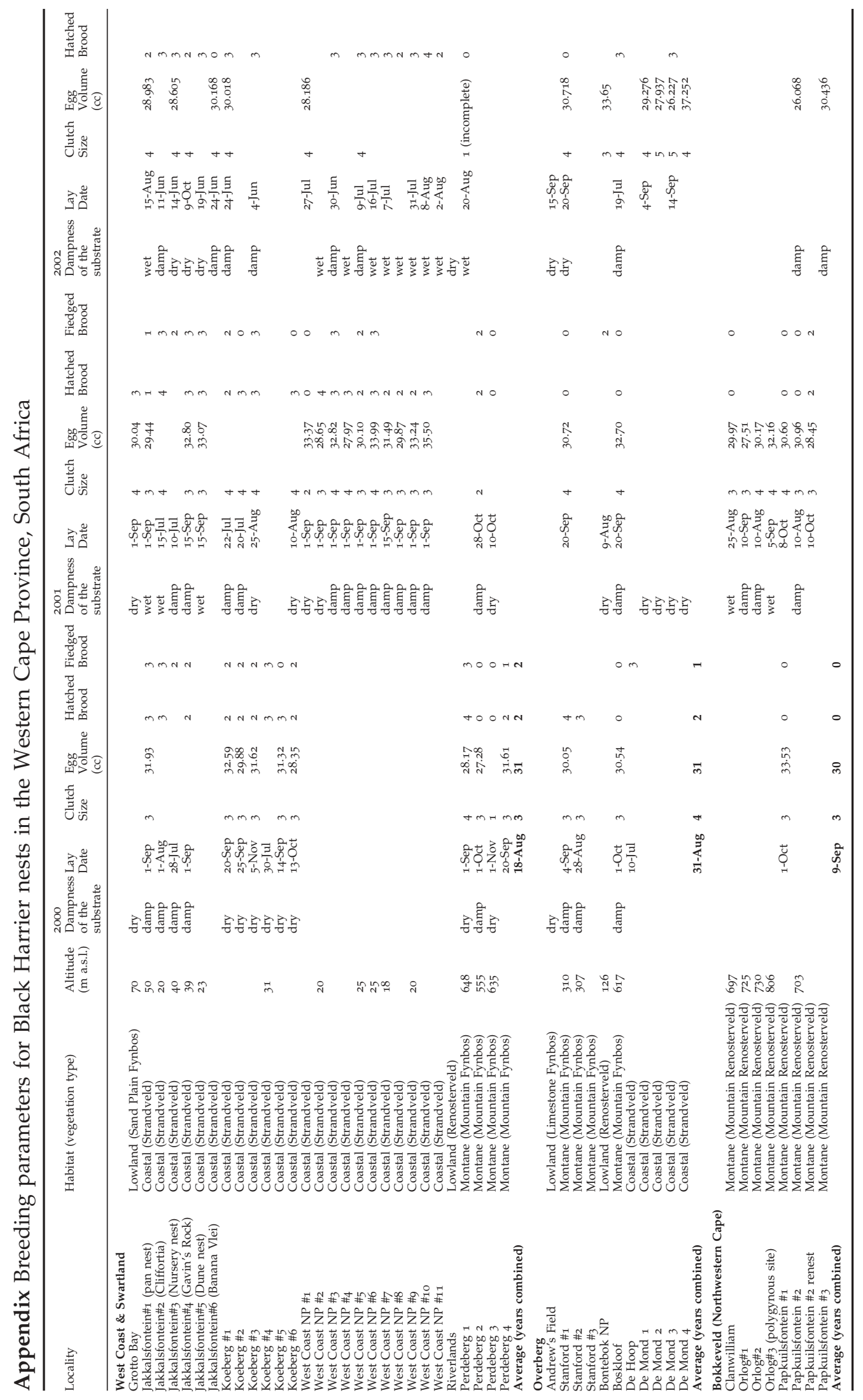


allowed us to conduct research in their respective conservation areas. The following individuals contributed enormously to the study by allowing us to work on their property, by locating and monitoring nests, or by reporting harrier sightings: Judy and Chris New (Slent), Neil MacGregor (Niewoudtville), Mr and Mrs G. Coetzee (Lucerne), Thys de Villiers (Boskloof), Mick and June D'Alton, Carrots Doyle, Wicus Leeuwner, Jonaby Fletcher, Martin Heydorn, Peter Albertyn, Roy Allison, Ann and Mike Scott, Heyne and Cheryl Brink, Shannon Brink, Langley Roberts, Brent Visser, Giorgio Lombardi (Overberg), Jo Johnson (Koeberg), Wilhem and Mariet van Wyk (Papkuilsfontein), Peter Steyn, Kevin Shaw (Western Cape Nature Conservation Board), Gert Greeff and Hilton Westman (Koeberg), Danie Pretorius (Jakkalsfontein), Wessels Pretorius (Oorlogskloof) and Wessel Wessels (Schildskloof).

\section{References}

Allan, D. G. (1993) Aspects of the biology and conservation status of the Blue Crane Anthropoides paradiseus, and the Ludwig's Neotis ludwigii and Stanley's N. Denhami stanleyi Bustards in southern Africa. Unpubl. M.Sc. thesis, University of Cape Town.

Allan, D. G., Harrison, J. A., Underhill, L. G., Herremans, M. and Hitchcock, W. A. (2001) The nest record scheme, Third edition. ADU guide 3: 1-43.

Arroyo, B., Garcia, J. T. and Bretagnolle, V. (2002) Conservation of the Montagu's Harrier (Circus pygargus) in agricultural areas. Anim. Conserv. 5: 283-290.

Barnes, K. (2000) The Eskom Red Data Book of birds of South Africa, Lesotho and Swaziland. Johannesburg: BirldLife South Africa.

BirdLife International (2000) Threatened birds of the world. Cambridge, U.K.: BirdLife International.

Chadwick, P. I. (1997) Breeding by Black Harriers in the West Coast National Park. J. Afr. Raptor Biol. 12: 14-19.

Garcia, J. T. and Arroyo, B. E. (2001) Effect of abiotic factors on reproduction in the centre and periphery of breeding ranges: a comparative analysis of sympatric harriers. Ecography 24: 393-402.

Hockey, P. A. R., Underhill, L. G., Neatherway, M. and Ryan, P. (1989) Atlas of the birds of the southwestern Cape. Cape Town: Cape Bird Club.

Jenkins, A. R. (2000) Variation in the quality of parental care at falcon nests in South Africa as evidence for postulated differences in food availability. Ardea 88(1): 17-31.

Kemper, J., Cowling, R. M., Richardson, D. M., Forsyth, G. G. and McKelly, D. H. (2000) Landscape fragmentation in South Coast Renosterveld, South Africa, in relation to rainfall and topography. Austral Ecol. 25: 179-186.

Low, A. B. and Rebelo, T. G. (1996) Vegetation of South Africa, Lesotho and Swaziland. South Africa: Department of Environmental Affairs and Tourism, Pretoria.

Millon, A., Bourrioux, J. L., Riols, C. and Bretagnolle, V. (2002) Comparative breeding biology of Hen and Montagu's Harrier: an 8-year study in north-eastern France. Ibis 144: 94-105.

Preston, C. R. (1990) Distribution of raptor foraging in relation to prey biomass and habitat structure. Condor 92: 107-112.

Redpath, S., Amar, A., Madders, M., Leckie, F. and Thirgood, S. (2002) Hen harrier foraging success in relation to land use in Scotland. Anim. Conserv. 5:113-118.

Redpath, S. M., Arroyo, B. E., Etheridge, B., Leckie, F., Bouwman, K. and Thirgood, S. J. (in press) Temperature and Hen Harrier productivity: from local mechanisms to geographical patterns. Ecography.

Siegfried, W. R. (1992) The conservation of the southern African avifauna. South Afr. J. Wildlife Res. 22: 61-64. 
Simmons, R. E. (1986) Food provisioning, nestling growth and experimental manipulation of brood size in the Redbreasted Sparrowhawk Accipiter rufiventris. Ornis Scand. 17: $31-40$.

Simmons, R. E. (1997) Black Harrier Circus maurus. Pp. 241-243 in J. A. Harrison, D. G. Allan, L. G. Underhill, M. Herremans, A. J. Tree, V. Parker and C. J. Brown, eds. The atlas of southern African birds. Vol. 1: Non-passerines. Birdlife, Johannesburg.

Simmons, R. E. (2000) Harriers of the world: their behaviour and ecology. Oxford: Oxford University Press.

Steyn, P. (1982) Birds of Prey of Southern Africa, their identification and life histories. David Philip, Cape Town.

van der Merwe, F. (1981) A review of the biology and status of the Black Harrier. Ostrich 52: $193-207$.

van Wyk, E. and van Hensbergen, B. (1995) Small mammal communities of Renosterveld patches and wheatfields in the southern Cape. In A. B. Low, and F. E. Jones, eds. The sustainable use and management of Renosterveld remnants in the Cape Floristic Region. Proc. Symp. FCC Report 1995/4. Kirstenbosch, Cape Town: Flora Conservation Committee, Botanical Society of South Africa.

ODETTE CURTIS, ROBERT E. SIMMONS and ANDREW R. JENKINS

Percy FitzPatrick Institute, University of Cape Town, Rondebosch 7701, South Africa

Received 2 September 2003; revision accepted 24 June 2004 